Ann. Génét. Sél. Anim., I978, 10 (2), I7I-I79.

\title{
SAP frequency in Saskatchewan Charolais cattle $^{(x)}$
}

\author{
W. E. HOWELL, * J. J. LAUVERGNE \\ Department of Animal and Poultry Science \\ University of Saskatchewan \\ Saskatoon, Canada, S7 NOWO \\ * Département de Génétique animale, I.N.R.A. \\ Centre national de Recherches zootechniques \\ 78350 Jouy-en-Josas, France
}

\section{Summary}

A survey among 350 breeders of Charolais in Saskatchewan, Canada, was undertaken in the fall of 1977. Useable replies were received from I 24 breeders on 3208 cows producing 32 I 8 calves. Among these there were I9 cases of hereditary SAP (Syndrome of Arthrogryposis and Palatoschisis) in neonates for a frequency of $0.59 \mathrm{p}$. roo. Following adjustments for percentage of Charolais breeding in the dams it was apparent from the complete data that the frequency of defectives calves was not significantly different from that observed in the pure breed inFrance. It is concluded that the frequency and penetrance of the SAP gene among Charolais in Canada are the same as in France : $q=0.20, w=0.12$ (mid sex) and that the latter is not influenced by the percentage of Charollais blood (which is contrary to former belief).

\section{I. - Introduction}

Studies of SAP (Syndrome of Arthrogryposis and Palatoschisis) in Charolais cattle have been mainly conducted in France and Canada and have been reviewed by LAUVERGNe and FAUCON (I976).

This syndrome has been demonstrated to be conditionned by a single autosomal recessive gene with a penetrance apparently varying with the percentage

(I) A Franco-Canadian project supported by FIAERBC (International Charolais Association, Nevers, France) and the CIFS of the French Ministry of Foreign Affairs, for travelling and lodging. 
of Charolais blood : quite low in the pure breed in France but approaching unity in the early generations of repeated back crossing with Charolais in Canada.

In France the data were obtained by methodical survey (LEFOR' et al., I977) whereas in Canada initial studies were conducted with data obtained only from affected herds voluntarily submitted by their owners (Saskatchewan work of NAWROT, I973) or from breeding studies in an experimental herd of known carriers (work in Alberta by BERG and GoONEWARDENE, I974).

In order to make comparisons with French data and to establish a base line for future monitoring comparisons of genetic load, it seemed necessary that a survey be conducted among Charolais breeders in Canada.

The present Saskatchewan survey was designed as a pilot study for that purpose.

\section{II. - Materials and methods}

A survey of calving results in 1977 was conducted by mail among $35^{\circ}$ randomly chosen members of the Canadian Charolais Association resident in Saskatchewan. Survey kits were distributed in September 1977 and the data forms recovered by the agricultural advisers in 42 of the districts of the province.

Information for all mating's involving some Charolais in both parents was requested as follows:

- breed composition, age and relationship of sires and dams,

- sex, breeding system (natural service or $\mathrm{AI}$ ) birth condition and nature of defects (if any) of their calves.

The breeders were also asked to indicate whether they had completed the forms from recorded data or from memory.

Each participant in the survey was provided with complete detailed instructions and data sheets. Pictorial and verbal descriptions of conditions associated with SAP were furnished from which the breeders could indicate the exact nature of the defects.

The survey was anonymous that is, no information was requested as to the identity of breeders or animals.

\section{III. - Results}

Returns were received from $5_{5} 6$ breeders. Of these 99 provided complete information, 25 were incomplete for minor items such as percentage Charolais of dams, breeding system (AI or natural), ages and distribution of defects other than SAP, twenty five were sufficiently incomplete to be unuseable and seven respondents had abandoned the cattle business because of continuing depressed prices.

A summary of the information received in completed forms is presented in table $\mathrm{I}$.

Nine of the I9 reported SAP calves were described as having their hind legs stretched towards the rear when in a cumbent position with the fetlock joints bent sharply forward. These were described as poorly muscled particularly in the shoulders, hips and thighs. Three of these also had their front legs bent and 
TABLE $Y$

Summary of information from I 977 survey of a sample of breeders of Charolais cattle in Saskatchewan Condensé des résultats de l'enquête de 1977 sur un échantillon d'éleveurs Charolais de la Saskatchewan

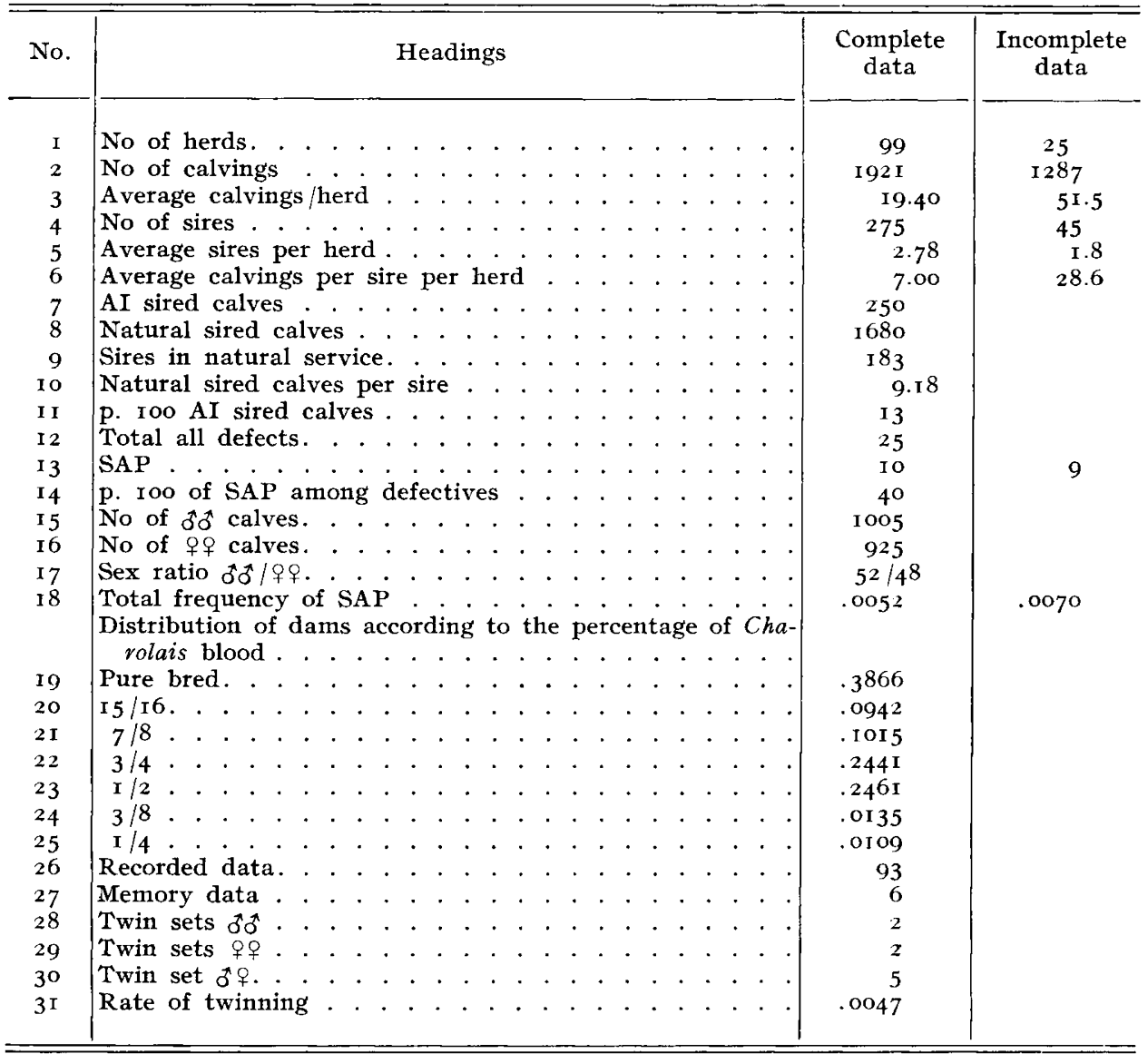

twisted inward at the knee and fetlock joints so that the soles of the feet were directed toward the head and one of these had a cleft palate.

Ten of the I9 reported cases of SAP displayed defective development of the front legs but not of the hind legs. In 7 of these, both front legs were bent and twisted inward at the knee and fetlock joints so the soles of the feet were directed toward the head. In three of them, only one front leg displayed the malformation and one of these had a cleft palate.

The I5 abnormalities not classified as SAP (on completed forms only) were of various types reported in many breeds with variable genetic components such as blindness, hip dislocation, polydactyly and swollen head (hydrocephalus?).

In table 2 are shown the frequencies of SAP according to the percentage of Charolais blood in the dams (3Ir of the sires were purebred Charolais and 9 were I5/I6 Charolais). 


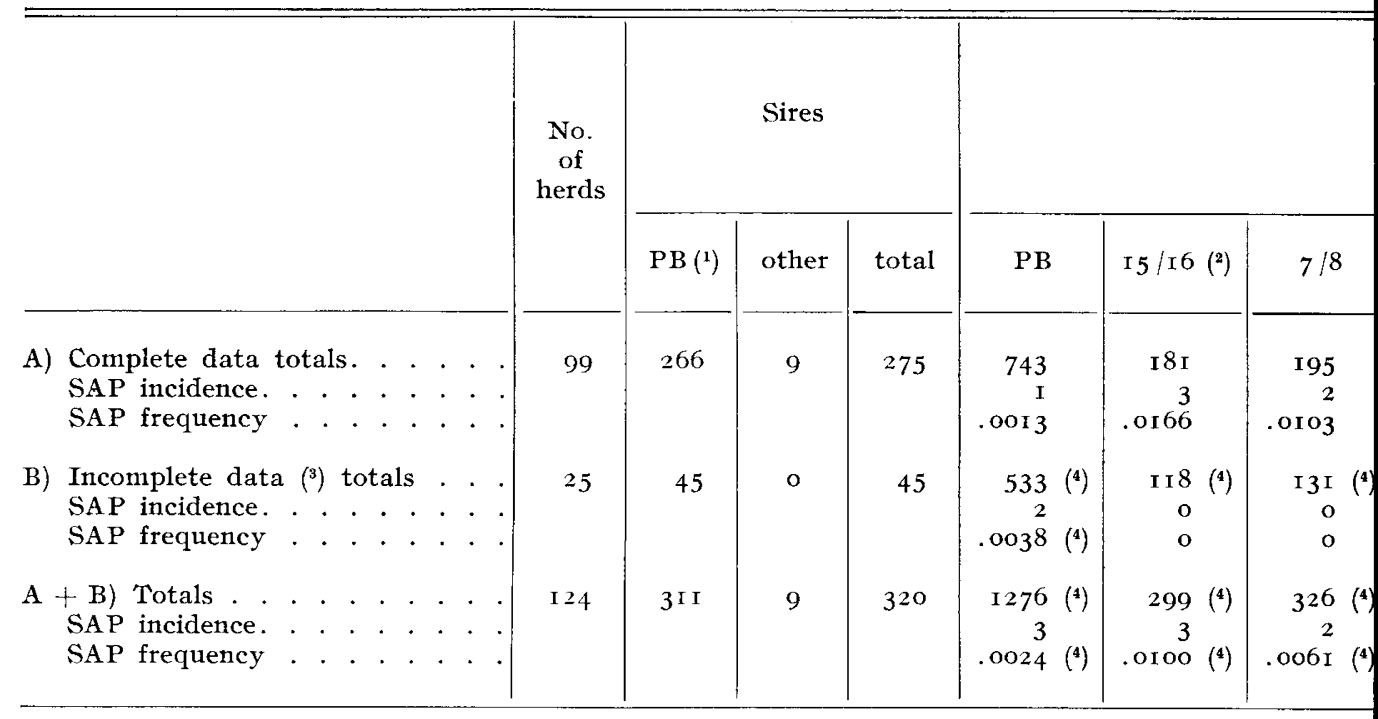

(I) Purebred Charolais.

(2) Fraction of Charolais breeding in the dams.

(3) Incomplete for breeding system (A.I. or natural), ages, distribution of percentage of Charolais dams ar

(4) Estimated values assuming that the frequency of different percentages of Charolais blood is the same

\section{IV. - Discussion}

Only forty five percent of the breeders ( 156 out of 350 ) replied at least partially. This may be due to a lack of time to complete the detailed form in large herds with many calves. As one can see (table I) the average herd size was 52 cows for the returns classified as incomplete compared with I9 cows in herds for which the returns were classified as complete. This alone would probably not introduce a bias to the data but some other fastors may explain non compliance such as having too many abiormals or none at all, lack of interest, peer influence... It is impossible to determine the effect of such factors in our case but a future survey must take account of these possibilities and their circumvention.

It is worth noting that $94 \mathrm{p}$. IOO of the respondants utilized written records of herd and animal performance (table r). Although $6 \mathrm{p}$. Ioo indicated the use of memory in completing the data form, these few averaged only Io Charolais matings none of which resulted in an SAP defective. It is also possible that records were available but had bean thoroughly committed to memory.

It is evident from hard ratios of sires used relative to number of Charolais calvings that the fewer such calvings the proportionately greater was the use of AI sires. Although an estimate of AI useage could not be derived from the 


\begin{tabular}{|c|c|c|c|c|c|c|c|c|c|c|c|}
\hline \multirow{2}{*}{\multicolumn{5}{|c|}{ Dams }} & \multicolumn{7}{|c|}{ Calves } \\
\hline & & & & & \multicolumn{3}{|c|}{ Normal } & \multicolumn{3}{|c|}{ SAP } & \multirow{2}{*}{ Total } \\
\hline $3 / 4$ & $I / 2$ & $3 / 8$ & $\mathrm{I} / 4$ & total & $\mathrm{M}$ & $\mathrm{F}$ & total & $\mathrm{M}$ & $\mathrm{F}$ & total & \\
\hline $\begin{array}{r}283 \\
3 \\
.0106\end{array}$ & $\begin{array}{r}472 \\
0 \\
0\end{array}$ & $\begin{array}{r}26 \\
1 \\
.0383\end{array}$ & $\begin{array}{r}2 \mathrm{I} \\
0 \\
0\end{array}$ & $\begin{array}{r}1921 \\
10 \\
.0052\end{array}$ & 999 & 921 & 1920 & 6 & 4 & ro & I930 \\
\hline $\begin{array}{r}226\left(^{(4)}\right. \\
5{ }^{4} \\
.0221\end{array}$ & $\begin{array}{r}266{ }^{(4)} \\
z \\
.0075{ }^{(4)}\end{array}$ & $\begin{array}{l}8\left(^{(4)}\right. \\
0 \\
0\end{array}$ & $\begin{array}{l}5\left(^{(4)}\right. \\
0 \\
0\end{array}$ & $\begin{array}{r}.1287 \\
9 \\
.0070\end{array}$ & $66 \mathrm{I}$ & 618 & I 279 & 4 & 5 & 9 & $\mathrm{I} 288$ \\
\hline $\begin{array}{r}509\left(^{(4)}\right. \\
8 \\
.0157\left({ }^{4}\right)\end{array}$ & $\begin{array}{r}738{ }^{(4)} \\
2 \\
\left..0027{ }^{4}\right)\end{array}$ & $\begin{array}{rr}34 & \left({ }^{4}\right) \\
I & \\
.0294 & \left({ }^{4}\right)\end{array}$ & $\begin{array}{l}26\left(^{(4)}\right. \\
\circ \\
0\end{array}$ & $\begin{array}{r}3208 \\
19 \\
.0059\end{array}$ & I 660 & I 539 & 3199 & Io & 9 & 19 & 3218 \\
\hline
\end{tabular}

incomplete data for the larger herds, 13 p. Ioo of Charolais calvings in the complete data file were reported as AI.

The secondary sex ratio (at birth) in this sample of I92I calvings for which data were complete was 52 o 0 for 48 우 which is exactly the same as the sex ratio observed in French Charolais, LEFORT et al. (I977).

Twinning frequency varies greatly among families within breeds but the 9 sets within this sample of I92I calvings (.0047) is in close agreement with estimates for other breeds of I set per 200 births.

The respondents furnishing complete data indicated in total the occurence of 25 defects among I92I neonates for a frequency of .or30 or I 3 in $x$ ooo births. Among these were Io identifiable cases of SAP giving a frequency of .0052 or 5 defective arthrogrypotic calves among $I$ ooo births. The leg and muscular defects reported were very similar to descriptions by LAUVERGNE and BLIN (I967), GREELEY et al. (I968), LEIPOLD et al. (I969) but the frequency of cleft palate among our cases (2: I9) is rather low being only II p. Ioo compared with $70 \mathrm{p}$. IOO in IIO SAP cases reported by LAUVERGNE (I975). This may be due to the fact that the survey was conducted after calving and many breeders had not checked the mouth for palate development before disposing of the calf.

Although there was reported in French data a significant sex effect (LEFORT et al., I977) on the incidence of SAP there is no such indication in our data but the sample is too small to verify such a discrepancy. 
The simplest hypothesis with which to test our data is whether the frequency of the gene in the French cattle imported into Canada are the same as in French Charolais cattle studied by LEFORT et al. (I977) and also whether the penetrance is the same for each percentage of Charolais blood in recurrent back cross generations as in purebred French Charolais.

Let $r$ be the percentage of Charolais blood in the females, $q$ the frequency of the gene for SAP and $w$ the mid sex penetrance of the abnormality among homozygotes.

The probability of observing one SAP calf in a cross between a Charolais bull and a female with $r$ per cent of Charolais blood is then $r q^{2} w$. Since $r q^{2} w$ is small the frequency of SAP in $n$ calvings from such crosses follows a Poisson distribution with parameter $n r q^{2} w$.

The expected values for the Poisson variables with $q=.20$ and $\bar{w}=. \mathrm{I} 2$ from LEFORT et al.'s paper (I977) among the various matings are given in table 3 with the corresponding observed values for the complete data.

\section{TABLE 3}

Testing the hypothesis that the frequency of SAP calves in the different Chatolais crosses in Saskatchewan has the same distribution as in pure French Charolais studied by LEFORT et al. (1977) (complete data)

Test de l'hypothèse selon laquelle l'apparition de veaux SAP dans les différents croisements Charolais de la Saskatchewan suit la même distribution que dans le Charolais étudié en France par LEFORT et al. (I977) (données complètes)

\begin{tabular}{|c|c|c|c|c|c|c|c|}
\hline & \multicolumn{7}{|c|}{ Percentage of Charolais blood of the mothers } \\
\hline & I & $15 / 16$ & $7 / 8$ & $3 / 4$ & $\mathrm{I} / 2$ & $3 / 8$ & $1 / 4$ \\
\hline $\begin{array}{l}\text { Expected values of the Poisson variable : } \\
\mathrm{E}=n v q^{2} w\end{array}$ & 3.42 & .78 & .78 & .98 & I.09 & .04 & .02 \\
\hline Observed values & I & 3 & 2 & 3 & o & I & o \\
\hline 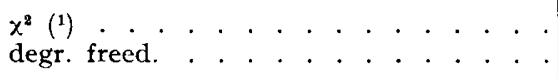 & & or & t & & $\begin{array}{c}3,28 \\
I\end{array}$ & & \\
\hline
\end{tabular}

(I) After grouping categories in order to have sufficient expected values.

One can see that there is no significant discrepancy between observed and expected values in complete data. There is perhaps a difficulty due to the abnormally high number of SAP in $3 / 4$ category among incomplete data if one assumes that the distribution of dams is the same as in complete data. But, in any cases, the penetrance among the calves born from dams with 50 p. roo of Charolais blood or less cannot be very high. In the complete data we have one SAP among 5I9 births, this observation is the value of a Poisson variable of ro.05 $w$ and the values of $w$ equal to or greater than .5 are rejected by statistical tests, the value of .I2 giving, on the contrary, a vey good agreement with the observed value. 
This result does not fit with the conclusions of NAwROT (r973) and of BERG and GOONEWARDENE (I974) of a penetrance increasing to unity as the percentage of Charolais blood was decreasing to 75 p. Ioo in the calf (dams being half Charolais).

The explanation of this discrepancy could possibly be connected to the following :

I $^{0}$ The inclusion of sampling bias, especially in the data analysed by NAwROT (1973). As seen consistantly in human genetical data the probability of sibship with abnormalities to be reported when more than one sib is affected is much higher than when only one sib is affected (see LI (I96I) on probability of ascertainment). NAwRoT's cases were mainly multiple and voluntarily submitted by breeders. Morever, some of the parents of SAP calves among this cases may have been homozygous normal overlap for the offending gene.

$2^{0}$ The results obtained in the experimental herd at Kinsella (Alberta) reported by BERG and GOONEWARDENE (r974) could be based on the effects of selecting breeding stock proven to be carriers thereby indirectly selecting for greater penetrance (reduction of suppressor modifiers).

\section{V. - Conclusion}

According to our findings, the frequency and penetrance of the SAP gene in Canadian Charolais is becoming very similar to that of France especially as the grading - up carries the population toward an increasing proportion of purebred animals (see in table $I$ the proportions based on percentage Charolais).

We have shown in a recent paper (LAUVERGNE and HowELI, 1977) that this situation precludes eradication of the gene at least in the Charolais population in France where there are relatively few progeny per bull. The Saskatchewan situation is even less amenable to such a process especially for the bulls used in natural service (less than 30 calves per bull per year, table I). And, even if all the AI bulls were proven non carriers, reduction in frequency of the gene would be very slow and eradication impossible since AI represents only I3 percent of all services in this sample (table I).

Application of expensive ared time-consuming test mating procedures to reduce the frequency of the offending gene is contra-indicated in Canada as in France, see LEFORT and LAUVERGNE (1974) for population genetic discussion.

Some practical conclusions in the more general field of monitoring defects in cattle by a field survey may be extracted from this study.

-. It is necessary to modify the survey data form in order to accomodate larger herds by requesting summarized rather than detailed data.

- It is necessary to code the form for confidentiality but to retain a method of access to the respondent for clarification.

- Personal contact rather than a mail-in survey would be desirable to avoid the introduction of biases resulting from incomplete information and nonrespondents.

- Better results would be obtained if breeders were briefed before the calving period from which information is to be gathered. 
- A method of assuring the ability of breeders to accurately identify defects is necessary.

- The participation of existing networks of district agricultural advisors is invaluable for this type of survey.

- Based on this pilot study and the foregoing comments an improved model can be structured for application to various of the breeds of the principal classes of domestic livestock for defect monitoring.

Reçu pour publication en juillet I978.

\title{
Aknowledgments
}

The valuable cooperation of the Agricultural Representatives of the Saskatchewan Department of Agriculture in conducting the survey is greatly appreciated.

We would like to thank also Dick KUNKEL, student assistant, Department of Animal and Poultry Science, University of Saskatchewan, for his technical assistance in designing the survey and assembling the data.

Professor G. LEFORT, Institut National Agronomique Paris-Grignon, France, has given valuable council in the mathematical treatment of the data.

\author{
Résumé \\ Fréquence de SAP dans le bétail Charolais de la Saskatchewan
}

Une enquête en ferme effectué en automne I977 a touché 350 éleveurs Charolais de la province de la Saskatchewan, Canada occidental. Cent vingt-quatre réponses portant sur 3208 vêlages (3 2 I 8 veaux) ont été utilisables. On a décelé I9 cas de 1'anomalie héréditaire SAP (Syndrome d'Arthrogrypose et de Palatoschisis) soit une fréquence de $0,59 \mathrm{p}$. roo. Après correction pour le pourcentage de sang Charolais il s'est avéré que la fréquence dans les différents groupes de données complètes classés selon le pourcentage de sang Charolais n'était pas significativement différente de celle observée en France en race pure. On conclut que la fréquence du gène récessif dans le Charolais pure race canadien tend à prendre la même valeur que dans le Charolais français : 0,2 de même que la pénétrance, également faible $(w=0,12$, moyenne entre sexe) et que celle-ci n'est pas influencée par le pourcentage de sang étranger au Chavolais, contrairement à ce qu'on avait pu penser.

\section{Réferences}

Berg R. T., Goonewardene L. A., I974. The genetics of Arthrogryposis in Charolais cattle. rst World Congr. Genet. appl. Livestock Prod., 1, 635-642.

GREELEY R. G., BOYD C. L., JolLy D. G., I968. Bovine anomalies and spastic paresis. Southwest Vet., 12, 277-280.

LAUVERGNe J. J., I975. État actuel des connaissances sur le Syndrome d'Arthrogrypose et de Palatoschisis (SAP) dans le bétail Charolais de France. Ann. Génét. Sél. anim., 7, 32 I-330.

Lauvergne J. J., Birin P. C., I967. Fissure palatine héréditaire associée à l'ankylose des membres dans la race Charolaise. Ann. Zootech., 16, 29r-3oo. 
Lauvergne J. J., Faucon A., I976. Le syndrome d'arthrogrypose et de palatoschisis (SAP) en race bovine Charolaise. Bibliographie annotée : 1967-1975. Ann. Génét. Sél. anim., 8, 5I-yo.

LAUVERGNe J. J., Howel. W. E., I977. Le syndrome d'arthrogrypose et de palatoschisis en race Charolaise : estimation de la fréquence, détection des porteurs et éradication. Note technique confidentielle rapportée à la FIAERBC (Nevers) par A. FAUCON, 7 p.

IEFORT G., I,AUVERGNE J. J., FABREGUE P., I977. Fréquence et pénétrances du gène responsable du Syndrome d'Arthrogrypose et de Palatoschisis dans le bétail Charolais en France. Ann. Génét. Sél. anim., 9, 283-3oo.

LI, C. C., I96r. Human Genetics. Mc Graw Hill, New-York.

NAwroT, P., I973. Arthrogryposis a congenital defect in newborn calves. M. S., Thesis Dpt anim. Sci., Univ. Saskatchewan, Saskatoon, $138 \mathrm{p}$. 